\title{
New case of krokodil (desomorphine) use
}

\author{
Savalan Babapoor-Farrokhran, Mario D. Caldararo, Sara Naji Rad, \\ Frederick N. Laborde, Rameez Rehman, Jose Mejia
}

\begin{abstract}
Introduction: Krokodil use was first reported in Siberia in 2002. The drug derives its name from the harms associated with its use, such as ulcerations and discolored necrotic scaled skin which may resemble crocodile skin. It has also been described as "flesh eating", as it finally disrupts the skin leaving the bone and muscle exposed to infections. Case Report: A 27-year-old female with past medical history of intravenous opioid dependence for 5-6 years and gastroesophageal reflux disease who presented with ulcerations of the posterior aspects of her arms bilaterally. The patient reported injecting krokodil for the past 5-6 months. She had been observing blue and black discoloration of the skin 1-2 days after each injection for the past 4-5 months. The injection site scabbed after 2-3 days. The patient continued injecting in area next to the affected sites. Eventually the affected sites coalesced and evolved into a large scab containing black necrotic tissue. In the last 5-6 days the black necrotic tissue started peeling off made the underlying tissue visible with mild
\end{abstract}

Savalan Babapoor-Farrokhran ${ }^{1,2}$, Mario D. Caldararo ${ }^{1}$, Sara Naji Rad², Frederick N. Laborde ${ }^{2}$, Rameez Rehman², Jose Mejia $^{2}$

Affiliations: ${ }^{1}$ Department of Internal Medicine, Thomas Jefferson University Hospital, Philadelphia, PA, USA; ${ }^{2}$ Department of Internal Medicine, Nassau University Medical Center, East Meadow, NY, USA.

Corresponding Author: Savalan Babapoor-Farrokhran, MD, Department of Internal Medicine, Thomas Jefferson University Hospital, Philadelphia, PA 19107, United States; Email: Savalan.babapoor@gmail.com

Received: 16 February 2018

Accepted: 10 March 2018

Published: 06 April 2018 greenish purulent discharge. She was treated with intravenous antibiotics and intensive wound care and was observed for opiate withdrawal. She was referred to plastic surgery for wound care and skin grafting. Conclusion: Krokodil is highly addictive and reports of its use began cropping up in the U.S. This case is the first case reported in New York.

Keywords: Desomorphine, Heroin, Krokodil, Necrotic wound

\section{How to cite this article}

Babapoor-Farrokhran S, Caldararo MD, Rad SN, Laborde FN, Rehman R, Mejia J. New case of krokodil (desomorphine) use. Int J Case Rep Images 2018;9:100901Z01SB2018.

Article ID: 100901Z01SB2018

$$
* * * * * * * * *
$$

doi: 10.5348/100901Z01SB2018CR

\section{INTRODUCTION}

Krokodil (also known as crocodile, croc, krok, desomorphine, dihydrodesoxymorphine, permonid, and poor man's heroin) use was first reported in Siberia in 2002 and became popular in Russia in 2003 [1]. It has been reported that there are more than 100 thousand people addicted to krokodil in Russia and about one third of them die every year [2]. The drug derives its name from the harms associated with its use, such as ulcerations and discolored necrotic scaled skin which may resemble crocodile skin. It has also been described as "flesh eating", as it finally disrupts the skin leaving the bone and muscle exposed to infections [3]. 


\section{EDORIUM Journals}

Krokodil has been spreading rapidly across Europe [1]. The presence of krokodil was confirmed in Poland, Germany, France, Belgium, Sweden and Norway [2]. It has been first reported in the US in Arizona in 2013 [4]. Other cases have been reported in Saint Luis Missouri in 2014 [5], and Cleveland in 2015 [6]. Here we report a young woman who has been admitted with progressive bilateral necrotic arm ulcers after intravenous abuse of Krokodil.

\section{CASE REPORT}

The patient is a 27-year-old female with past medical history of opioid dependence for $5^{-6}$ years and gastroesophageal reflux disease (for $2-3$ years) who presented to the hospital with ulcerations of the posterior aspects of her arms bilaterally (Figure 1). At the time of admission, she had mild pain and itching on both arms. The patient reported using krokodil for the past 5-6 months. Last use of intravenous krokodil was four days prior to admission. She had been observing blue and black discoloration of the skin 1-2 days after each injection for the past $4-5$ months. The injection site scabbed after $2-3$ days. The patient continued injecting in area next to the affected sites. Eventually the affected sites coalesced and evolved into a large scab containing black necrotic tissue. In the last 5-6 days the black necrotic tissue started peeling off made the underlying tissue visible with mild greenish purulent discharge.

The patient reports using alprazolam and cocaine. She has smoked 15 pack years and is a current every day smoker. The patient has been injecting heroin into her arms for the past 5-6 years and is a daily heroin and krokodil (for 5-6 months) user, with 30 bags (50-100 $\mathrm{mg} / \mathrm{bag}$ ) a day dissolved with tap water and about six intravenous shots per day into her arms. While in the hospital, she was treated with intravenous antibiotics and intensive wound care along with precautions for opiate withdrawal. The patient was referred to plastic surgery for

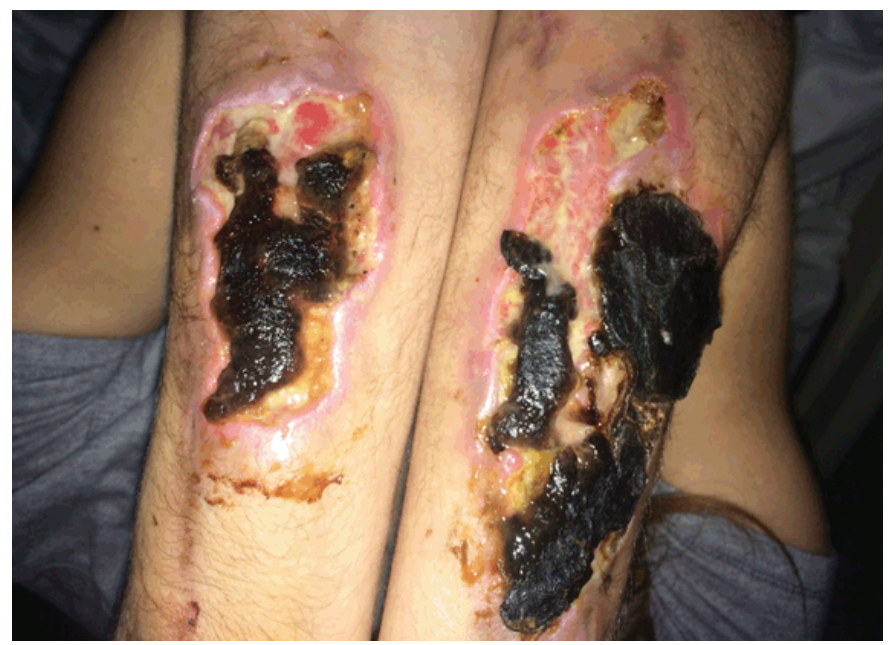

Figure 1: Photograph demonstrating bilateral upper extremity of the patient with necrotic ulcer and scar tissue. wound care and skin grafting. Unfortunately, the patient was lost to follow-up despite attempts to reach her.

\section{DISCUSSION}

Krokodil is a blend of few chemicals. The main active ingredient is desomorphine, a synthetic derivative of morphine, from codeine. It is significantly cheaper than heroin and hence the name "poor man's heroin." Other easily available low-cost additives used in the production of krokodil include red phosphorus (scraped from striking surfaces of matchbook), iodine, gasoline, hydrochloric acid, and a diluting agent (usually paint thinner). Krokodil production requires minimal laboratory equipment and it takes up to 45 minutes to synthetize the drug. Due to the nature and variety of these additives, there is high potential for contamination [1].

Krokodil is estimated to be $8-10$ times more potent than morphine regarding its analgesic effect. It has faster onset of action, and shorter half-life compared to morphine [7]. The analgesia caused by krokodil causes users to seek medical attention much later, after a significant amount of necrosis has already begun $[1,7,8]$. The high likelihood of contamination with different toxic chemicals and byproducts from their chemical reactions with one another has been hypothesized to be the reason why krokodil is more often associated with gangrenous and necrotic tissue destruction than other intravenously injected illicit substances, including heroin $[9,10]$.

The most common complication of krokodil is vascular damage and skin and soft tissue infection resulting in necrosis and gangrene as seen in this case. It also increases risk of HIV and HCV transmission. Other reported complications are thrombosis of major vessels, osteomyelitis, subcutaneous abscess, serious systemic damage, neurological damage including speech and motor skill impairment, endocrine damage due to iodine content, memory and concentration impairment, and personality changes [1].

Uncomplicated cellulitis and soft tissue infection in the setting of intravenous drug abuse most often responds to antibiotics against $\mathrm{S}$. aureus and Streptococcal species. Most of the cases require surgical interventions including debridement, incision and drainage. In complicated cases, appropriate antibiotics should be chosen based on cultures and sensitivities [11].

Management of patient requires multidisciplinary approach including medicine, infectious disease, plastic surgery, psychiatry and social worker teams. In addition to medical and physical attention patients also require emotional and social support [12].

\section{CONCLUSION}

Although the prevalence of krokodil in the United States continues to be much lower than heroin use, the 


\section{EDORIUM Journals}

use of this dangerous highly addictive drug has been increasing. As evidenced by this case, the drug has now reached New York.

\section{REFERENCES}

1. Grund JP, Latypov A, Harris M. Breaking worse: The emergence of krokodil and excessive injuries among people who inject drugs in Eurasia. Int J Drug Policy 2013 Jul;24(4):265-74.

2. Skowronek R, Celinski R, Chowaniec C. "Crocodile": New dangerous designer drug of abuse from the East. Clin Toxicol (Phila) 2012 Apr;50(4):269.

3. Veronese K. Krokodil: Russia's designer drug that will eat your flesh. November 2011. [Available at: http:// io9.com/5859291/krokodil-russias-designer-drugthat-will-eat-your-flesh]

4. Gaynor T. First cases of flesh-eating narcotic Krokodil suspected in U.S. Reuters. September 2013. [Available at: http://www.reuters.com/article/2013/o9/26/ usa-arizona-krokodil-idUSL2NoHM2FX20130926]

5. Thekkemuriyi DV, John SG, Pillai U. 'Krokodil': A designer drug from across the Atlantic, with serious consequences. Am J Med 2014 Mar;127(3):e1-2.

6. Canales M, Gerhard J, Younce E. Lower extremity manifestations of "skin-popping" an illicit drug use technique: A report of two cases. Foot (Edinb) 2015 Jun;25(2):114-9.

7. Bognar R, Makleit S. Neue methode fürdie vorbereitung von dihydro-6-desoxymorphine. (A new method for the preparation of dihydro6-desoxymorphinan). Arzneimittelforschung 1958;6:323-5.

8. Alves EA, Soares JX, Afonso CM, et al. The harmful chemistry behind "krokodil": Street-like synthesis and product analysis. Forensic Sci Int 2015 Dec;257:7682.

9. Katselou M, Papoutsis I, Nikolaou P, Spiliopoulou C, Athanaselis S. A "krokodil" emerges from the murky waters of addiction. Life Sci 2014 May 2;102(2):81-7.

10. Gahr M, Freudenmann RW, Hiemke C, Gunst IM, Connemann BJ, Schönfeldt-Lecuona C. Desomorphine goes "crocodile". J Addict Dis 2012;31(4):407-12.

11. Ebright JR, Pieper B. Skin and soft tissue infections in injection drug users. Infect Dis Clin North Am 2002 Sep;16(3):697-712.

12. Iyer S, Subramanian P, Pabari A. A devastating complication of 'skin popping'. Surgeon 2011 Oct;9(5):295-7.

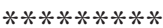

\section{Author Contributions}

Savalan Babapoor-Farrokhran - Substantial contributions to conception and design, Acquisition of data, interpretation and analysis of data, Drafting the article, Revising it critically for important intellectual content, Final approval of the version to be published Mario D. Caldararo - Substantial contributions to conception and design, Revising the article critically for important intellectual content, Final approval of the version to be published

Sara Naji Rad - Substantial contributions to conception and design, Revising the article critically for important intellectual content, Final approval of the version to be published

Frederick N. Laborde - Substantial contributions to conception and design, Revising the article critically for important intellectual content, Final approval of the version to be published

Rameez Rehman - Substantial contributions to conception and design, Revising the article critically for important intellectual content, Final approval of the version to be published

Jose Mejia - Substantial contributions to conception and design, Revising the article critically for important intellectual content, Final approval of the version to be published

\section{Guarantor of Submission}

The corresponding author is the guarantor of submission.

\section{Source of Support}

None

\section{Consent Statement}

Written informed consent was obtained from the patient for publication of this case report.

\section{Conflict of Interest}

Authors declare no conflict of interest.

\section{Copyright}

(C) 2018 Savalan Babapoor-Farrokhran et al. This article is distributed under the terms of Creative Commons Attribution License which permits unrestricted use, distribution and reproduction in any medium provided the original author(s) and original publisher are properly credited. Please see the copyright policy on the journal website for more information. 
Access full text article on other devices

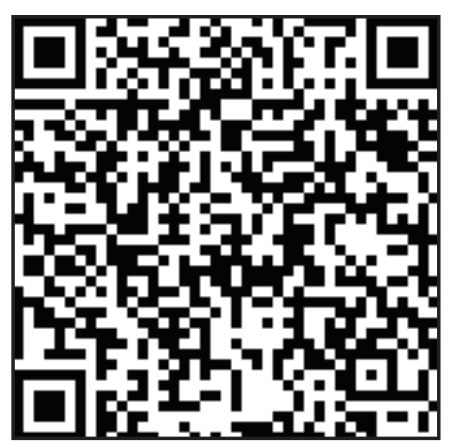

Access PDF of article on other devices

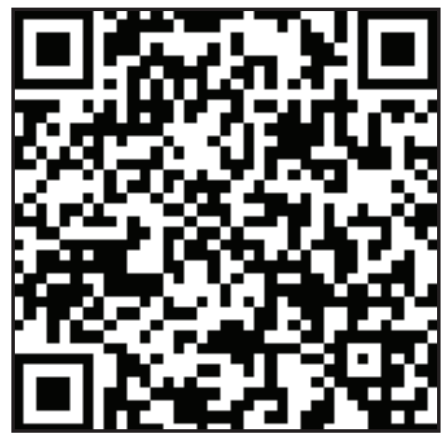

